\title{
Sağlık ve Çevre Etkileşimine AB Perspektifinden Yaklaşmak
}

\author{
Muzaffer Akdoğan ${ }^{1}$ \\ Didem Saygın² \\ İlknur Gül ${ }^{3}$
}

\section{Öz}

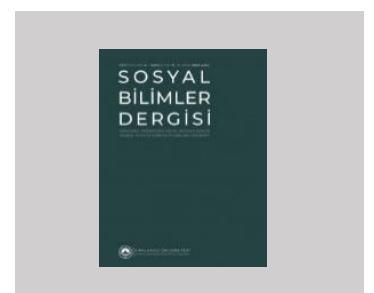

Makale Türü Araştırma Makalesi

Başvuru Tarihi 17.11.2021

Kabul Tarihi

22.12.2021

DOI

10.47140/kusbder.1024972

Jel Kodu

I18, Q53
En geniş tanımıyla çevre, bizi çevreleyen herşeydir ve tüm canlıların yaşam alanıdır. Bu gruba dahil insan ile içerisinde yaşadığı çevre, sürekli ve karşılıklı olarak birbirini etkilemektedir. İnsanın bugün ve gelecekte refah içinde bir hayat sürdürebilmesi için temiz ve sağıkı bir çevrede yaşaması gereklidir. Bu açıdan bakıldığında insan sağ $ı$ ı̆ı ve refahı ile çevrenin durumu yakından ilişkilidir. İnsan sağlığının korunması, ancak çevrenin korunması ve kirletilmeden kullanılması ile mümkündür. Avrupa Birliği çevrenin korunmasına dair önemli ve oldukça geniş bir mevzuat oluşturmuş ve bu mevzuatı insan sağlığının korunmasının önceliği üzerine inşa etmiştir. Bu çalışmada, Avrupa Birliği'nde çevre-sağlık ilişkisinin içeriği ve sağlığın çevre üzerindeki etkisi incelenmiştir. Çalışmada betimleyici araştırma modeli tercih edilerek konu deskriptif yöntemle ele alınmıştır. Çalışmada varılan sonuç şudur ki, insan ve halk sağlığı bağlamında sağlık; çevresel eylem ve işlemlerinin şekillenmesinde belirleyici bir etkiye sahiptir. Bu bağlamda insan sağlığının korunmasının, Birlik'in tüm eylem ve kararlarında öncelikli bir hedef haline geldiğini ve hatta çevrenin korunmasının da büyük ölçüde önüne geçtiğini söylemek mümkündür.

Anahtar sözcükler: Avrupa Birliği, çevre sağlığı, halk sağlığı, insan sağ|ı̆̆ı, çevre politikası.

${ }^{1}$ Sorumlu Yazar: Dr. Öğr. Üyesi, Sağlık Bilimleri Üniversitesi, Hamidiye Sağıık Bilimleri Enstitüsü, Sağlık Hukuku Anabilim Dalı, E-posta: muzafferakdogan@gmail.com, https://orcid.org/0000-0002-9999-0969

${ }^{2}$ Dr. Öğr. Üyesi, Çanakkale Onsekiz Mart Üniversitesi, Biga İktisadi ve İdari Bilimler Fakültesi, Kamu Yönetimi Bölümü, Hukuk Bilimleri Anabilim Dalı, E-posta: didemsaygin@gmail.com, https://orcid.org/0000-0002-2832$351 X$

${ }^{3}$ Araştırma Görevlisi, Kırklareli Üniversitesi, İktisadi ve İdari Bilimler Fakültesi, Siyaset Bilimi ve Kamu Yönetimi Bölümü, Hukuk Bilimleri Anabilim Dalı, E-posta: ilknur.gul@klu.edu.tr, https://orcid.org/0000-0002-7701-0800 


\title{
Approaching Health and Environment Interaction from the European Union Perspective
}

\author{
Muzaffer Akdoğan ${ }^{4}$ \\ Didem Sayg $\mathrm{n}^{5}$ \\ İlknur Gül ${ }^{6}$
}

\begin{abstract}

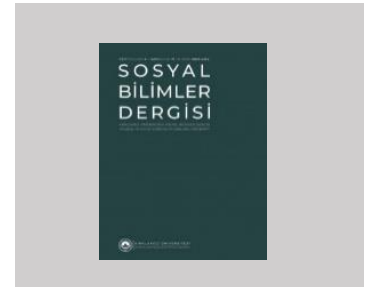

Article Type

Research Article

Submit Date

2021-11-17

Acceptance Date

2021-12-22

DOI

10.47140/kusbder.1024972

Jel Kodu

118, Q53

In its broadest definition, the environment is everything that surrounds us and is the habitat of all living things. The people and the environment where they live affect each other mutually and continuously. In order to maintain healthy and wealthy life, it is necessary for people to live in a clean and healthy environment. From this point of view, human health and well-being and the state of the environment are closely related. The protection of human health is only possible with the protection of the environment and its usage without pollution. European Union has created very significant and very extensive legislation on the protection of the environment and has built this legislation on the priority of the protection of human health. In this study, the content of the environmental-health relationship in the European Union and the impact of health on the environment are examined. This study has been handled with a descriptive method The conclusion of the study is that; in the context of human public health, health has a decisive effect in shaping environmental actions and processes. While the protection of human health has become a priority target in all actions and decisions within the Union, this situation has considerably prevented the protection of the environment.

Key words: European Union, environmental health, public health, human health, environmental policy.

\footnotetext{
${ }^{4}$ Corresponding Author: Asst. Prof, Sağlık Bilimleri University, Hamidiye Institute of Health Sciences, Department of Health Law, E-mail: muzafferakdogan@gmail.com, Https://orcid.org/0000-0002-9999-0969 ${ }^{5}$ Asst. Prof, Çanakkale Onsekiz Mart University, Biga Faculty of Economics and Administrative Sciences, Department of Public Administration, E-mail: didemsaygin@gmail.com, https://orcid.org/0000-0002-2832-

${ }^{6}$ Research Assitant, Kırklareli University, Faculty of Economics and Administrative Sciences, Department of Political Science and Public Administration, E-mail: ilknur.gul@klu.edu.tr, Https://orcid.org/0000-0002-77010800
} $351 X$
\end{abstract}




\section{Giriş}

1950'lerde oluşumuna başlayan Avrupa Birliği (AB) o günlerden bu günlere değin sürekli kendini geliştiren ve zaman zaman da genişleten bir süreçten geçmiştir. Avrupalı devletlerin bütünleşme hareketi olarak da adlandırabileceğimiz bu süreçte Birlik hem coğrafi sınırlarını genişleterek büyümüş hem de politika alanlarını genişleterek derinleşmiştir. Giriştiği kurumsal/yasal reformlarla enerjiden güvenliğe, eğitimden çevreye, kültürden kamu sağlığına kadar bir çok temel politika alanında dönüşüm gerçekleşmiş ve gerçekleşmeye de devam etmektedir.

Birçok Avrupalıya AB hakkında ne düşündüğü sorulsa, ilk akla gelen yanıtlar tek pazar, tarım politikası, Avro, sosyal politikalar ve istihdam, ortak bir Avrupa dışişleri ve güvenlik politikası oluşturma girişimleri ve son zamanlarda yaşanan COVID-19 ile ilgili sağlık tartışmaları olacaktır. Bu yanıtlar Avrupalı halkın yaşamını doğrudan etkileyen politika alanlarını göstermesi açısından doğal karşılanmalıdır. 1970'li yıllardan beri içerdiği temalar sürekli genişleyen ve diğer politika alanlarıyla sıkı ilişki içinde olan çevre politikası ise, halkın mevcut durumundan kötüye gitmediği sürece özel anlam yüklediği bir alan olmayacaktır.

Oysa ki, insan ve halk sağlığı, çevre ile yakından ilintilidir. Çevrenin kalitesi, insan ve halk sağığı kadar refahı da etkileme potansiyeline sahiptir. Bu nedenle insan ve halk sağlığının çevresel konularda vurgusunun giderek arttığı ve hatta belirleyici olduğunu söylemek mümkün ise de çevre ve sağ|ığın birbirlerine temas ve tesir eden sınırlarını ortaya koymak sanıldığı kadar kolay değildir. Zira insan sağlığını korumayı amaçlayan tüm faaliyetlerin çevresel bir boyutunun olduğunu veya olmadığını belirlemek her zaman mümkün olmayabilir. Çevresel kirleticilerin insan sağlığı üzerindeki etkisinin yorumlanması, sağlığı etkileyen birçok faktör bulunmasından dolayı oldukça zordur.

$A B^{\prime}$ de çevre-sağlık ilişkisine yönelik durum tespitinin yapıldığı bu çalışma, üç ana başlıkta oluşturulmuştur. Öncelikle çevre ve sağlık ilişkisi kavramsal düzeyde ele alınmış ve arkasından $A B^{\prime}$ nnin çevre-sağlık ilişkisine dair yaklaşımını anlamak için konu hem yetki hem politik hem de hukuki yönden ayrı ayrı analiz edilmiştir. Son başlıkta ise AB çevre mevzuat setine dahil yasal çerçeve incelenmiş ve sağlık ile ilişkisi kurulmaya çalışılmıştır.

\section{Çevre ve Sağlık ilişkisi: Kavramsal Çerçeve}

İnsan doğduğu andan itibaren bir çevrenin içerisindedir ve kendisi gibi canlı bir varlık olan çevre ile sürekli ve zorunlu bir birliktelik halindedir. Bu birliktelikte insan, çevreyi özellikle Endüstri Devrimi'nden sonra kendi ihtiyaçlarını karşılayacak bir kaynak olarak görmeye başlamış ve karşııkı ilişkideki dengeyi kendi lehine bozmuştur. 20. yüzyılın ikinci 
yarısından itibaren ise -özellikle Rachel Carson'ın 1962 yılında yayınlanan "Sessiz Bahar"7 isimli kitabının yayınlanmasından bu yana- insanın çevre üzerindeki üstünlüğünün zayıfladığı tartışımaya başlanmıştır. Özellikle 1972'de Roma Kulübü tarafından yayımlanan "Büyümenin Sınırları" isimli raporda insanlığın geleceğine ilişkin olumsuz öngörülerde bulunulmuş ve ekonomik büyümenin çevre üzerinde tahribata sebep olduğu ve doğal kaynakların sonsuz olmadığı ısrarla vurgulanmıştır (Club of Rome, 1972). Doğal kaynakların tükenebilirliğinin yanı sıra iklim değişikliği, biyolojik çeşitliliğin kaybı gibi durumlar da insanlık için birer tehdit oluşturmaktadır. Günümüzde insana düşen görev, çevreyi korumak ve çevreye zarar vermeden, çevrenin sürdürülebilirliğini bozmadan tüketmektir.

Esasen insan çevreyi kendini korumak için de korumalıdır. İnsan sağlığı, çevresel faktörlerle yakından ilişkilidir. Havanın ve suyun temizliği, gıda ihtiyacının karşılanması için verimli toprakların varlığı, üretim için gerekli girdiler noktasında kaliteli çevresel varlıklar oldukça önemlidir. Ayrıca doğa (yeşil yapının varlığı) iklim düzeninin korunması kadar doğal afetlerin önlenmesine de yardımcı olmaktadır. Bu alanlara ulaşmak rekreasyon için önemli olanaklar sağlarken refahı da desteklemektedir. Bununla birlikte çevre, kişilerin gürültüye, kirli havaya, tehlikeli ve zararlı olan kimyasallara maruz kaldığı kanallar arasında oldukça önemli bir yerdedir. Dünya Sağlık Örgütü (World Health Organization/WHO), sağlıklı çevrenin oluşturulmasıyla hastalıkların önlenmesine ilişkin sunduğu raporunda Avrupa Bölgesi içinde 53 devletteki tüm ölümlerin \%12-18'inde çevreye dayalı stresin etkili olduğunu tahmin etmektedir. Su, gürültü ve hava gibi önemli kilit alanlarda çevrenin kalitesini yükseltmek, hastalıkların önüne geçerek insan sağlığını daha iyiye taşıyabilir (European Environmental Agency [EEA], 2019). Örneğin Kemseke'ye (2020) göre tüm dünya gibi Avrupa'yı da derinden sarsan COVID-19 pandemisi büyük ölçüde bir çevresel krizdir. Bu açıdan yaklaşıldığında çevresel varlıkların bozulmadan korunması veya bozulduğunda iyileştirilmesi halinin halk sağlığının korunmasında bir nev'i koruyucu hekimlik görevi icra ettiği söylenebilir.

İnsanlar uzun zamandır çevrede onları hasta edebilecek maddelere/kirleticilere maruz kalmaktadır. Ancak kirleticiler ve insan sağlığı arasındaki ilişkiyi anlamak göründüğünden daha zordur. Çünkü sorun sadece kirleticinin içerdiği kimyasallardan kaynaklı sağıık

\footnotetext{
${ }^{7}$ Carson çevre hareketlerinin başlamasında etkisinin büyük olduğu bilinen bu kitabına Albert Schweitzer'den atıfla "Insanlar geleceği görme ve önlem alma yeteneklerini kaybettiler. Dünyayı yok ederek kendi sonlarını da hazırlıyorlar" cümleleriyle başlamıştır. Kuş cıvıltılarının olduğu bir kasabanın ölüm sessizliğine nasıl büründüğünü çarpıcı bir dille anlatıldığı kitapta, insanın geleceği öngörmeksizin gerçekleştirdiği sorumsuz davranışlarıyla toprağa attığı zehirli kimyasal ilaçların yalnızca bitkiye, hayvana değil insan sağlığına da negatif etkileri gösterilmiştir (Carson, 2004). Çevre bilincinin oluşumunda bir devrimi gerçekleştiren Carson'ın fikirleri, dikloro difenil trikloroetan (DDT)'nın yasaklanması ile de somut uygulama alanı bulmuştur.
} 
problemleri değildir. Örneğin, insanlar bu maddeye nasıl maruz kalmaktadır? Nefes aldıklarında onu soluyarak mı, derilerinden emerek mi içerek mi, yiyerek mi? Kirletici, içinde büyüdüğü topraktan veya beslendiği bitki örtüsünden besine mi girmektedir? Hangi tür çözümler kirletici maddenin çevrede yaygınlığını azaltmaya yardımcı olabilir? İnsanlar maruz kaldıktan sonra sağlıklarını bir maddeye karşı en iyi nasıl koruyabilirler? (Hoover, 2019, s. 3). Bu sorular yeni değildir. Yeni olmadığı gibi bunları çoğaltmak da mümkündür, fakat sağlığın çevre ile ilişkisini net olarak ortaya koymanın zorluğuna dikkat çekmek için yeterlidir.

Çevre, insan faaliyetleri sonucunda ortaya çıkan hasardan faaliyeti yapanların etkilendiği bir ortamdır. Kirleticiler; havayı, suyu veya toprağı zehirli maddelerle kirletmek suretiyle, kirletilen çevre ile temas eden kişilerin sağlığına dolaylı olarak zarar vermektedir (Ortolani, 2016, s. 186). Ancak, çevresel kirleticilerin insan sağlığı üzerindeki etkileri hakkında net yorumlar yapmak zordur, çünkü sağığı yalnızca kirleticiler değil aynı zamanda genetik arka plan, yaş, cinsiyet gibi birçok faktör de etkilemektedir. Hatta bu faktörlerin aynı anda varlığı ve/veya kirleticilerin içerdiği kimyasalların değişen derecelerde var olması halinde çevre ve sağlık konuları iç içe geçmiş olacak, kesin sınırlar konulamayacaktır (Rautio, 2016, s. 83). Bununla birlikte, günümüzde birçok hastalığın görülme sıklığının arttığı ve özellikle de çevresel varlıklardaki bozulmalarla karşı karşıya kalan nüfusun sağlığının negatif yönde etkilendiği rahatlıkla söylenebilir.

Bu konuda ortaya konan çalışmalar çevresel risklerin toplum düzeni içerisinde eşit dağılmadığını ve toplumsal düzende dezavantajlı ve korunmasız nüfusun olumsuz etkilendiğini göstermektedir. Özellikle hamilelik gibi hassas bir süreçte, yaşlılık, erken çocukluk gibi yaşam evrelerinde farklı kimyasal madde kullanımlarına maruz kalmak sağlığa yönelik ciddi endişelerin kaynağıdır. Bunlara ek olarak, insanların sosyoekonomik durumu, maruz kalınan çevresel stres kaynaklarını etkiler. Bozulmuş bir çevrede yoksul insanların yaşama olasılığı daha yüksektir ve toplumdaki dezavantajlı gruplar, mevcut sağlık durumları ve yetersiz beslenme koşulları ile birlikte sigara içme veya hareket etmeme gibi olumsuz davranışlardan dolayı çevresel stresin etkilerine yönelik daha duyarlı olabilirken, çevresel risklere uyum sağlama ve risklerden kaçınma hususunda sınırlamalarla da karşılaşabilirler (EEA, 2019). Özetle, dezavantajı grupların bozulmuş bir çevrenin kümülatif etkilerinden genellikle olumsuz etkilendiğini ve bu tür maruziyetten kaçınmak için finansal, eğitimsel ve kültürel kapasiteden yoksun olduğunu da söyleyebiliriz.

Son yıllarda çevre ve sağlık arasındaki ilişkide politik bağlamda da değişiklikler yaşanmaktadır. Avrupa Çevre Ajansının raporlarında da belirtildiği gibi politikanın odağı, çevre kirliliğine tek noktadan bakıp tek bir sonuç görmek yerine bir bütün olarak 
ekosisteme, ekosistem direncinin korunmasına ve ekosistem hizmetlerinin insanlığa sunulmasına ilişkin sistemik zorluklara doğru kaymaktadır. İklim değişikliği; gıda ve su güvenliği, sıcak hava dalgaları, sel riskleri üzerindeki birleşik etkileriyle iyi bir örnektir (EEA, 2013, s. 5). İklim değişikliği gibi doğal kaynakların tükenmesi, biyolojik çeşitliliğin kaybı ve ekosistemlerin bozulması halleri de sistemik bozulmalarla karşı karşıya olan bir dünyada çevresel risklerin karmaşıklığını göstermektedir.

\section{Avrupa Birliği'nin Çevre ve Sağlık iliş̧kisine Yaklaşımı}

Avrupa'daki en büyük çevresel sağıı riski hava kirliliğidir. Hava kirliliği kalp hastalığı, akciğere dair hastalıklar ve felç ile yakından ilişkilidir. Maruz kalınan hava kirliliğinin, $A B^{\prime}$ de her yıl 400.000'den fazla erken ölüme neden olduğu tahmin edilmektedir. Ayrıca ulaşım ve endüstriden kaynaklı gürültüye maruz kalma, uyku bozuklukları, huzursuzluk ile bunlara bağlı olarak kardiyovasküler ve hipertansiyon hastalık riskinde artışa neden olabilmektedir. Bununla birlikte, çevreden kaynaklı sağlık zararlarından doğan davalarda başarılı olmak ve tazminat almak için, davacılar genellikle birkaç tür problemle karşı karşıya kalmaktadır. Haksız fiil davalarındaki davacılar için, olaylarla zarar arasındaki nedensellik bağının yeterince kanıtlanması sorunu üstesinden gelinmesi en zor olanlardan biridir, çünkü birçok kirleticinin insan sağlığı üzerindeki etkileri hala tam olarak anlaşı(a)mamıştır ve zararlı bir etkiyi belirleyici olarak tek bir nedene bağlamak her zaman mümkün değildir. Bu sorunlar, gerçek hasarın genellikle hasar verici olaydan yıllar veya bazen on yıllar sonra meydana gelmesi gerçeğiyle daha da büyümektedir (Ortolani, 2016, s. 187). Bu itibarla çevre-sağlık ilişkisinden doğan anlaşmazlıklarda yargılamanın sağlıklı bir şekilde yürütülmesi hem teknik hem de bilimsel verilerin ışığında ancak mümkündür.

Avrupa entegrasyonunun motivasyonuyla $A B$, üye devletlere göre çevre sorunlarına çözüm arayan çevre politikası alanında, ulusal düzeyden ziyade bölgesel düzeyde daha etkilidir. Bu etkinin sonucunda, hava ve su kalitesi, gürültü kirliliği, kimyasalların kontrolü, atık yönetimi, pestisitlerin kullanımı, balıkçılık yönetimi, enerji verimliliği, asit yağmuru ve iklim değişikliği gibi çok çeşitli konuları ele alan ve çerçevesi genişleyen bir mevzuat ortaya çıkmıştır. Bu tür konularda ortak bir çözüm üzerinde anlaşmaya varmak her zaman kolay olmamıştır, zira AB politikasının etkileri karışıktır. Ancak Avrupa düzeyinde çevreyle ilgili politikalar geliştirmek için gösterilen çabalar, daha temiz, daha sessiz ve daha sağlıklı bir AB'de yaşamak için yardımcı olmaktadır (McCormick, 2001, s. ix).

Bölgesel entegrasyonun etkileri daha geniş bir şekilde anlaşıldıkça, çevrenin Avrupa politikaları üzerindeki baskısı artmıştır. Avrupalıların artan zenginliği onları yalnızca iyi eğitimin sağlanması, sağlık hizmetlerinde iyileştirmeler ve temiz hava ve su sağlama çabaları gibi nitel konularla daha fazla ilgilenmeye teşvik etmekle kalmamış, aynı zamanda 
bölgesel entegrasyonun çevresel konulara çekilmesine yardımcı bir dizi etkisi olmuştur (McCormick, 2001, s. 3).

İnsan sağlığının korunması, çevre politikası sınırlarının büyük ölçüde ötesine geçen bir hedeftir, çünkü insan sağ|ığını korumayı amaçlayan tüm faaliyetlerin çevresel bir boyutu yoktur ve bazen bunun tersi de geçerlidir. AB hukukunun ve politikasının hiçbir yerinde, halk sağ|ığının çıkarlarının nerede sona erdiği ve çevrenin kalitesiyle ilgili endişelerin başladığı açıklanmamaktadır. Bu iki amaç genellikle AB faaliyetlerini meşrulaştırmak için kullanılmıştır (McCormick, 2001, s. 23).

\section{Yetki yönünden}

Avrupa Birliği'nin İşleyişine IIlişkin Antlaşma (Treaty on the Functioning of the European Union/TFEU)'nın 3-6 maddelerinde $A B$ kurumları ile $A B$ üye devletleri arasındaki yetki dağılımı yapılmıştır. Bu dağııma göre kimi yetkiler münhasır olarak $A B^{\prime} y e$, kimi yetkiler üye devletlere verilirken iki tarafın da kullanımına bırakılan ortak yetkiler de söz konusudur. TFEU 4. maddesine göre Birlik, Antlaşmaların kendisine 3. ve 6. maddelerde belirtilen alanlarla ilgili olmayan bir yetki sağladığında üye devletlerle bu yetkiyi paylaşacaktır. Birlik yetkilerinin sınırları, müzakere ilkesi gereğince yönetilir. Birlik, yetkilerin kullanımında bağlılık ve orantılılık ilkelerine tabidir (Treaty on European Union [TEU], Madde 5/1). Bütünlük ilkesi uyarınca Birlik ancak Antlaşmalarda üye devletlerin burada belirtilen hedeflere ulaşmak için kendisine verilen yetki sınırları dahilinde hareket etmelidir. Birlik'e Antlaşmalarda verilmeyen yetkiler ise üye devletlerindir (TEU, Madde $5 / 2)$.

Tablo 1. Sağlık ve Çevre ile Illgili Yetkilerin Sınıflandırılması

\begin{tabular}{lll}
\hline Konu & Yasal Dayanak & Yetki Türü \\
\hline Çevre & TFEU madde 4/2 (e) & Paylaşılmış yetki \\
\hline $\begin{array}{l}\text { Halk sağlığı konularında ortak } \\
\text { endişeler }\end{array}$ & TFEU madde 4/2 (k) & Paylaşılmış yetki \\
\hline $\begin{array}{l}\text { Insan sağlığının korunması ve } \\
\text { iyileştirilmesi }\end{array}$ & TFEU madde 6 (a) & Tamamlayıcı yetki \\
\hline
\end{tabular}

Tablo 1.'de görüldüğü üzere TFEU madde 4/2 (e) ve (k) uyarınca, hem çevre politikasının sağlık yönlerine ilişkin yetkileri hem de halk sağlığı konularında ortak güvenlik endişeleri paylaşılmaktadır. Öte yandan, insan sağlığının korunması ve iyileştirilmesi, TFEU madde 6 (a) sayesinde tamamlayıcı bir yetki olarak kabul edilmiştir. TFEU'nun 6. maddesi hükmünce Birlik, üye ülkelerin eylemlerini destekleyip, koordine etmek veya tamamlamak için eylemler gerçekleştirme yetkisine sahiptir. Dolayısıyla Birlik, bu madde kapsamında 
sayılan şu alanlarda üye devletleri destekleyici eylemlerde bulunabilir: İnsan sağlığının korunması ve iyileştirilmesi; endüstri; kültür; turizm; eğitim, mesleki eğitim, gençlik ve spor; sivil korunma; idari işbirliği. Görüldüğü üzere insan sağlığının korunması ve iyileştirilmesi öncelikli olarak listenin başında yer almaktadır. Birlik, üye devletlerin eylemlerini bu alanda destekleme, kontrol etme veya tamamlama yetkisini yasal olarak elde etmiş durumdadır. Bununla birlikte yetki dağılımında, çevrenin de $A B$ ve üye devletlerin ortak yetki alanında kaldığını belirtmek gerekir. Sağlık ve çevre konularında $A B^{\prime}$ nin müstakil bir yetkiyle donatılmadığının burada altını çizmek önemlidir.

Üye devletler, Birlik içinde halen olmazsa olmaz temel yapı taşları olarak kalmakla birlikte bu devletler, devletlerarası örgütlerde görülen ve devletlerin egemen eşitliğine dayanan basit işbirliği düzeyinin çok ötesindedir. Öyle ki herhangi bir alanda AB'nin mi yoksa üye devletlerin mi daha etkin olduğu bakış açısına göre değişse de yetkilerin kademeli olarak Avrupa düzeyine (ulusüstü kurumlara) taşınıyor olması ulusal yasama organlarının daha zayıf ve marjinal kaldığı yorumunu besleyen bir sürece işaret etmektedir. Ulusal yasama organları, neredeyse mutlak otoriteye sahipken AB'nin daha az aktif olduğu alanlarda bu otoriteyi kullanır halde kendilerini bulmaya başlamıştır. Üye devletler bölgesel entegrasyonun baskısı altında $A B$ düzenlemeleri ne istiyorsa onu yapmaktadır. Bu noktada Avrupalı vatandaşların haberi olmadan yetkilerin büyük oranda $A B$ kurumlarına aktarıldığı iddia edilmektedir (McCormick, 2014, ss. 214-216). Dolayısıyla, AB hukukunun ulusal sağlık hizmetleri sistemleri üzerinde de uzun süredir devam eden ve artan bir etkisi olduğuna dikkat çekilmektedir (Hervey ve Vanhercke, 2010, s. 84).

Avrupa içinde sağlık hakkının uygulanması, giderek bir $A B$ meselesi halini almaktadır. Geleneksel olarak Birlik, özellikle iç pazarın işleyişi ile ilgili alanlarda (çalışma koşulları, çevre, tüketim ürünleri, ilaçlar ve tıbbi cihazlar vb.) sağlığın korunmasına odaklanmıştır. Bununla birlikte halk sağ|ığına yönelik Birlik eylemleri, üye ülkelerin sağlık hizmetlerinin ve tıbbi bakımın organizasyonu ve sunumuna ilişkin sorumluluklarına tam olarak saygı göstermek durumundadır. Bir başka anlatımla, sağlık hizmetlerinin organizasyonu ve finansmanında üye devletlerin Birlik hukukuna uygun olarak sorumluluklarını yerine getirmeleri gerekse de bu alanda yetki ve otorite üye devletlerin elindedir (Gevers, 2004, s. 32).

\section{Politika yönünden}

$A B^{\prime}$ nin kuruluşunda herhangi bir çevre politikası bulunmazken, çevre bürokrasisi ve çevre yasasına da rastlanmaz. Avrupa Ekonomik Topluluğu (AET), o zamanlar olduğu gibi, öncelikle ekonomik refahı artırmak ve savaşın yıktığı Avrupa'da siyasi ilişkileri onarmak için benzer düşünen altı devlet arasında hükümetler arası bir anlaşma hüviyetindedir. İngiltere'nin Topluluk'a katılmasıyla (1973) birlikte çok sınırlı sayıda çevre politikası 
benimsenmiştir, ancak bunlar da öncelikli olarak insan sağ|ığını korumaya ve ticaretin önündeki iç engelleri kaldırmaya yönelik olmuştur (Jordan, 2005, s. 1).

AB çevre politikasının gelişimi beş aşamaya ayrılabilir. İlk aşama, AET'nin 1972 Paris Zirvesi ile başlamıştır. İkinci aşama, Paris Zirvesi'nden 1987 Avrupa Tek Senedi'nin kabul edilmesine kadar geçen süreyi kapsamaktadır. Üçüncü aşama, Senedin yürürlüğe girdiği andan itibaren Maastricht Antlaşması'na kadar sürmüştür. Dördüncü aşama Maastricht Antlaşması'nın yürürlüğe girmesinden Lizbon Antlaşması'na gelmektedir. Beşinci aşama 2009 Lizbon Antlaşması́nın yürürlüğe girmesinden günümüze kadar uzanmaktadır. Başlangıçta, Avrupa entegrasyonu yalnızca ekonomik bir entegrasyon olduğundan 1958'de yürürlüğe giren ve AET'yi kuran Antlaşma, çevreye atıfta bulunmamış veya çevreyi korumaya yönelik herhangi bir hüküm içermemiştir (Nakanishi, 2016, ss. 2-3).

Çevre politikası, Avrupa Tek Senedi'nden bu yana düzenlenecek faaliyet alanlarından ziyade ulaşılacak hedefler açısından tanımlanmaktadır. Özellikle 1987 yılında Avrupa Tek Senedi ile Topluluk'un çevre sorunları hususunda adım atmasına açıkça yetki verilmesi ile ilgili maddeler kurucu metinlere dahil edilmiştir. Maastricht Antlaşması'nın yürürlüğe girmesi ile 1993 yılında çevre konusunda mevcut politika alanlarının bir kısmı güçlendirilmiştir (Aydın ve Çamur, 2017, s. 27). Şöyle ki, AB çevre politikası ile kirliliği azaltıp bu yönde çalışmaları arttırarak kirliliği önlemeyi hedeflenmiş; doğal kaynakların ekolojik düzene zarar vermeyecek şekilde kullanılması amacıyla sürdürülebilir kalkınma desteklenmiştir (T.C. Dışişleri Bakanlığı Avrupa Birliği Başkanlığı, 2020). Bu bağlamda Maastricht Anlaşması'yla çevre alanına "politika" statüsü verilmiştir denilebilir.

1 Aralık 2009 tarihinde yürürlüğe giren Lizbon Antlaşması ile de çevre, üye ülkeler ile AB arasında paylaşılan yetki alanlarından biri olarak kabul edilmiştir. Bu Antlaşma uyarınca, Birlik'in çevre politikası, aşağıdaki hedeflerin takibine katkıda bulunmaktadır:

- Çevre kalitesinin koruma altına alınması ve iyileştirilmeye çalışılması,

- İnsan sağ|ığının korunması,

- Doğal kaynakların bilinçli/ihtiyatlı ve rasyonel bir şekilde kullanılması,

- Bölgesel veya dünya ölçeğindeki çevre sorunlarına yönelik uluslararası alandaki tedbirlerin destekleyici olması ve iklim değişikliğiyle mücadele edilmesi (TFEU madde 191/1).

TFEU'nun 3/3 maddesi uyarınca da sürdürülebilir kalkınma ve dolayısıyla çevre koruma hedefi, iç pazardan ayrı tutulamaz. Bu hükmün 3. paragrafı, bu hedefleri eşit bir zemine oturtmaktadır. Bu nedenle karşıtlıktan çok uzlaşma üzerinden analiz edilmeleri gerekmektedir. Bununla birlikte, çevresel kaygılar izole değildir; ekonomik entegrasyon 
hedeflerine yardımcı olarak kabul edilen diğer politikalarla da örtüşmektedir. Özellikle tüketici, sağlık ve çevre politikaları kendi aralarında bir dizi ortak özelliği paylaşmaktadır (Sadeleer, 2014, s. 5).

Esasen, tüm politika alanları birbiriyle etkileşim halindedir. Çevre, belki de herhangi bir politika alanından daha fazla hemen hemen tüm diğer alanları hem etkiler hem de faaliyetlerden etkilenir. Çevrenin en çok sanayi, ekonomi, tarım, enerji, ulaşım, su temini, sanitasyon, kentsel ve kırsal kalkınma ve sağlık hizmetleri ile ilgili politikalarla ilişkisi açıktır (McCormick, 2001, s. 3).

Çalışma konusu açısından bakıldığında ise, çevre ve sağlık politikaları arasında önemli farklılıklar olduğu öncelikle dikkate alınmalıdır. Kurumsal düzeyde Avrupa Topluluğu Antlaşması'nı ve daha sonra TFEU'nun çerçevesini çizenlerin çevre politikasını sağlık politikası ile eşit bir zemine koymadıkları belirtilmelidir. Bu nedenle, her iki politikanın eylem araçları kurumsal düzeyde önemli ölçüde farklılık göstermektedir (Sadeleer, 2014, s. 135).

$A B$ sağlık politikası aslında paradoksal bir özellik göstermektedir. Bir yandan $A B$ antlaşmaları Birlik'e esas olarak ulusal düzenlemelere bırakılan sağlık konusunda oldukça sınırlı bir rol vermekteyken diğer yandan sağlık, sosyal güvenlik sistemlerinin koordinasyonu gibi doğrudan ilgili birçok alanda $A B$ öncelikler belirlemekte ve politika yapım sürecini yönlendirmektedir. $A B$ üye devletleri arasında hareket eden göçmen işçilerin sağlık hizmetlerine erişimi, çevre, gıda güvenliği ve iş güvenliği gibi alanlarda sağlığın iyileştirilmesi konularında ve ayrıca, iç pazar düzenlemeleri, para ve mali politikalar konusunda $A B$ kapsamlı bir yetkiyle halk sağlığı ve sürdürülebilirliği üzerinde önemli bir etkiye sahiptir (McKee, 2017, s. 243).

Bununla birlikte $A B^{\prime}$ nin her iki alanda yapılan/yapılacak araştırmalar için önemli bir finansman programı bulunmaktadır. Çerçeve Programları olarak da adlandırılan Araştırma ve Teknolojik Geliştirme Çerçeve Programları tarafından finanse edilen projeler, Avrupa'da ve ötesinde bilinçli politika kararları almak için gerekli bir bilgi tabanının oluşturulmasına katkıda bulunmaktadır (Karjalainen, 2016, s. 249). Buna ek olarak, çevre ve sağıı araştırmaları yalnızca bilimsel bilgi tabanının oluşmasına katkıda bulunmamaktadır. Bu projelere aynı zamanda Avrupanın ortak sorunlarını ele alarak bir çözüm için sinerji yaratması açısından da ihtiyaç duyulmaktadır.

1984'ten bugüne Çerçeve Programlar, Avrupa ve ötesindeki çok disiplinli araştırma ve işbirliği faaliyetlerinde lider bir rol oynamıştır. Beşinci Çerçeve Programı (ÇP-5) tarafından finanse edilen çevre ve sağlık araştırması, özel bir çevre ve sağlık araştırma faaliyetinin ortaya çıktığı ilk $A B$ araştırma çerçeve programıdır. Bunun nedeni, çevre ve sağlık 
sorunlarına yönelik artan halk endişeleri ve bu alanda gelişen AB politikalarını destekleme ihtiyacıdır (Karjalainen, 2016, s. 250).

Tablo 2. ÇP-5, ÇP-6 ve ÇP-7'deki Çevresel Belirleyicilere Odaklanan Finanse Edilen Proje Sayısı

\begin{tabular}{lllll}
\hline Proje Konuları & ÇP-5 & ÇP-6 & ÇP-7 & Toplam \\
\hline Endüstriyel kimyasallar & 39 & 21 & 35 & 95 \\
\hline Birden çok veya tanımlanmamış faktör & 3 & 17 & 19 & 39 \\
\hline Nano-materyaller & 3 & 7 & 42 & 52 \\
\hline Yaşam tarzı faktörleri & 2 & 1 & 17 & 20 \\
\hline Iyonlaştırıcı radyasyon & 14 & 4 & 15 & 33 \\
\hline Hava kirliliği & 20 & 1 & 9 & 30 \\
\hline iklimsel faktörler & 2 & 5 & 14 & 21 \\
\hline Biyolojik tehlikeler & 7 & 3 & 7 & 17 \\
\hline Iyonlaştırıcı olmayan radyasyon & 8 & 2 & 8 & 18 \\
\hline Gürültü & 5 & 1 & 2 & 8 \\
\hline
\end{tabular}

Kaynak: (Karjalainen, 2016, s. 253)

5. ÇP'den bu yana çevre ve sağlık araştırmalarının ana politika itici gücü, Avrupa Çevre ve Sağlık Stratejisi ve 2004 yılında kabul edilen ve 2010'un sonunda tamamlanan ilgili Eylem Planı olmuştur. Projeler ÇP-5 kapsamında finanse edilen bu Stratejinin oluşturulmasına katkıda bulunmuştur. Strateji ve eylem planı, çevresel faktörler ve sağlık arasındaki bağlantıların daha iyi anlaşımasını amaçlamıştır (Karjalainen, 2016, s. 253). Bununla birlikte program çevre mevzuatında başarı sağlamış olsa da çevre politikasının diğer politikalarla ilişkisinde gereken ilgiyi görememiştir (Çokgezen, 2007, s. 95).

Son yıllarda, çevresel kirleticiler ve bunların insan sağlığı üzerindeki riskleri hakkındaki önemli soruna yaklaşmak için çeşitli girişimlerde bulunulmuştur. AB'nin 6 . ve 7. Çerçeve Programları çerçevesinde, çevresel kirleticilerin insan sağlığı üzerindeki etkilerine odaklanan projeler oluşturulmuştur (Rautio, 2016, ss. 85-86). Özellikle 6. Çerçeve Programı iklim değişikliği konusunu önemle vurgulamış ve iklim değişikliğiyle ilgili olarak Kyoto Protokolü'nün onaylanması ve $A B^{\prime}$ nin bu Protokolün gereklerini yerine getirmesi hedeflenmiştir (Türkeş ve Kılıç, 2004, s. 40). AB tarafından finanse edilen bu projelerin çoğunun odak noktası, politika yapıcılara çevresel kirleticilerin durumu ve Avrupa, Kuzey Kutbu ve diğer ülkelerdeki insan sağlığı için riskleri hakkında bilgi vermek, onlara ulaşmak ve tavsiyelerde bulunmak için ağlar oluşturmak olmuştur. Bu projeler; daha fazla işbirliğini, insan biyo-izleme programlarının ve çalışma tasarımlarının uyumlu hale getirilmesini, ulusal gruplardan ortak veri tabanlarının oluşturulmasını ve kirletici 
seviyeleri ile insan sağ ığı arasındaki nedensel ilişki hakkında daha fazla kanıta sahip olmak için havuzlanmış numuneler yapılmasını önermektedir (Rautio, 2016, s. 89).

Son 10 yılda, $A B$ tarafından finanse edilen birkaç projede, çevresel kirleticilere maruz kalma ve insan sağlığı arasındaki ilişkilere yönelik önemli sonuçlara ulaşılmış ve çok disiplinli araştırmaya yönelik yaklaşımlara yöenlimler olmuştur: İklim değişikliği, çevre ve insan sağlığı ile epidemiyolojik ve mekanik çalışmalardaki araştırmacılar arasında işbirliği; ve ayrıca insan sağ|ı̆̆ı için kontaminant maruziyet riskini tahmin etmede küçük örneklem büyüklüğündeki problemleri veya metodolojideki ve çalışma tasarımındaki farklılıkları çözmek için yeni izleme ve araştırma ağları ve ortak veri tabanları oluşturmak gibi (Rautio, 2016, s. 94). Bu gelişmeler bizlere her iki politika alanının da, öngörülebilir gelecekte önemini koruyacağını göstermektedir.

\section{Hukuki yönden}

Çevrenin sağlık hakkı ile ilişkisinin kurulduğu bu yaklaşımda; tüketicinin iç pazar ortamında dolaşan ürün veya hizmetlerden zarar görmemelerinin sağlanması, AB hukuk düzeni içinde güvenlik ve tüketiciyi koruma standartlarını belirlemektedir. Dolayısıyla, tek pazarın çevreyi olumsuz etkilemediğinden emin olmak için, $A B$ çevre hukukunun büyük bir bölümü hava ve su kalitesi ile atıkların bertaraf edilmesi gibi konuları kapsamaktadır (Hervey, 2010, s. 6).

TFEU'nun 168/1 maddesi sayesinde "tüm Birlik politikalarının ve faaliyetlerinin tanımlanmasında ve uygulanmasında yüksek düzeyde insan sağlığı koruması sağlanacaktır". TFEU'nun 168. maddesinin AB sağıı hukukunun ana odağını oluşturduğu kabul edilse de yüksek düzeyde sağıık korumasını bu madde ile sınırlamak doğru değildir. Diğer konularda da yüksek düzeyde sağlık koruması yasal olarak uygulanmaktadır (serbest dolaşım hükümleri, tüketici ve çevre koruma, sosyal politika, rekabet politikası, vb.). TFEU'nun bu hükümlerini destekler mahiyette olan AB Temel Haklar Şartı (EU's Charter of Fundamental Rights/EU CFR)'nın 35, 37 ve 38. maddeleri yüksek düzeyde sağlık, çevre koruma ve tüketicinin korunmasını gerektirmektedir (EU CFR, 2012).

TFEU'nun 168/7 maddesine göre, sağıı hizmetleri ve tıbbi bakımın yönetimi ve kaynakların tahsisi konusunda yetkili olan $A B$ değil üye devletlerdir. Bununla birlikte, sağlığın yaygınlaştırılmasının izlerini 1980'lerin ortalarında ortaya çıkan Antlaşma'da bulmak mümkündür. İlk olarak Avrupa Tek Senedi ile Antlaşma'ya eklenen TFEU'nun 
114/3 maddesine (eski madde 95/TEC) göre ${ }^{8}$, iç pazar mevzuatı "sağlık, güvenlik, çevre koruma ve tüketicinin korunması" ile ilgili konularda yüksek düzeyde koruma sağlamalıdır (TFEU, 2012).

Önlem ilkesi sadece çevrenin korunmasına ilişkin olarak TFEU'da belirtilmiştir (Madde 191/2), ancak kapsamı, TFEU’nun 11. maddesindeki yatay hükmün varlığından da anlaşılacağı üzere çok daha geniştir. Birçok çevre koruma önlemi halk sağlığını korumayı amaçlamaktadır ve bu hedef, AB çevre politikasının TFEU 191/1 ve 169/1 maddeleri uyarınca "insan sağlığının korunmasına katkıda bulunmak" amacına sahip olması gerçeğiyle pekiştirilebilir. Dolayısıyla, genel olarak çevrenin korunmasına ve daha özel olarak insan sağlığının korunmasına katkıda bulunan bir önlemin TFEU'nun 36. maddesi kapsamına girmesi tamamen mümkündür. Örneğin, kullanım ömürlerinin sonunda lastiklerin birikimi insanlar için riskle ilişkilendirilen atık haline gelir. Tropikal bölgelerde, üreme alanı olarak atık lastikleri kullanan sivrisinekler yoluyla dang humması, sarı humma ve sıtmanın bulaşması, insan yaşamı ve sağlığı için belirli riskler içermektedir. Bu nedenle, atık lastiklerin olumsuz etkilerini en aza indirmek için düzenleyici önlemler almak, halk sağ|ı̆̆ını iyileştirmeyi amaçlamaktadır (Sadeleer, 2014, s. 293). TFEU’nun 36. maddesinde ortaya konan kamu yararı zemini, "insanların ve hayvanların veya bitkilerin sağlığının ve yaşamının korunmasıdır". Bu kamu yararı zemini çevrenin korunmasıyla ilgilidir, ancak bunlarla uyumlu değildir. Dolayısıyla, hem insanların ve hayvanların veya bitkilerin sağlığının ve yaşamının korunması hem de çevrenin korunması, üye devletlerin malların serbest dolaşımına müdahale ederken meşru olarak izleyebilecekleri kamu politikası hedefleri olarak hizmet edebilir. Bu nedenle üye devletler, devre dışı bırakma önlemlerini alırken nadiren ek sağlık veya çevre gerekçelerine başvurabilirler (Dederer, 2016, s. 162).

Çevreyi korumayı amaçlayan $A B$ önlemlerinin çoğu, mutlak bir koruma düzeyi aramamaktadır. ${ }^{9}$ Aşağıdaki açıklamalar, AB kanun koyucu tarafından onaylanan sınırlı yaklaşımın bir kanıtıdır. Örneğin, AB kurumları veya ulusal makamlardan aşağıdakilerin meydana gelmesini ortadan kaldırması veya önlemesi istenmektedir:

- Bitki koruma ürünleri kalıntılarının 'çevre üzerinde kabul edilemez etkisi’nin;

\footnotetext{
8 illgili madde hükmü: "Komisyon, sağlık, güvenlik, çevre koruma ve tüketicinin korunmasına ilişkin 1. paragrafta öngörülen tekliflerinde, özellikle bilimsel gerçeklere dayanan yeni gelişmeleri dikkate alarak, yüksek düzeyde koruma sağlayacaktır. Kendi yetkileri dahilinde, Avrupa Parlamentosu ve Konsey de bu amacı gerçekleştirmeye çalışacaktır."

${ }^{9}$ Ancak, sağlığın korunmasına ilişkin yasal düzenlemeler uyarınca, AB müdahalesi belirli bir eşiğe tabi değildir. Özellikle bkz.:, European Parliament and Council Regulation (EC) No 178/2002 of 28 January 2002 laying down the general principles and requirements of food law, establishing the European Food Safety Authority and laying down procedures in matters of food safety. [2002] OJ L31/1 (Madde 7/1). Bu madde hükmü kapsamında, yüksek düzeyde sağlık korumasını sağlamak amacıyla, 'sağlık üzerinde zararlı etki olasılığını' önlemek için 'geçici risk yönetimi önlemleri' benimsenebilir. Bu etkilerin önemi için herhangi bir eşik belirlenmemiştir.
} 
- Bitki koruma ürünleriyle işlenmiş tohumların 'insan ve hayvan sağlığı veya çevre için taşıdığı ciddi risk'in;

- Genetiği değiştirilmiş gıda ve yemlerin piyasaya sürülmesine ilişkin ‘bir izni acilen askıya almak veya değiştirmek' için 'insan ve hayvan sağ|ı̆̆ı veya çevre için taşıdığı ciddi risk'in.

Burada geçen 'ciddi risk' nitelemeleri, insan ve hayvan sağlığını veya çevreyi açıkça tehlikeye atan önemli bir risk olarak anlaşılmalıdır. Bu risk, güvenilir bilimsel verilere ve yeni kanıtlara dayanılarak tesis edilmelidir. Benzer şekilde üye devletler, 'çevre üzerinde önemli etkileri olması muhtemel projeleri' değerlendirmekle yükümlüdür. Buradan, önemsiz risklerin bir dizi $A B$ düzenleme planının kapsamı dışında kalması muhtemeldir. Aynı şekilde, $A B$ Mahkemeleri de $A B$ kurumlarından ve üye devletlerden çevre riskinin gerçek veya önemli olup olmadığını değerlendirmelerini talep etmektedir (Sadeleer, 2014, s. 50).

Çevre politikası, $A B$ politika faaliyetinin en hızlı genişleyen alanlarından biri olurken bu durum $A B$ çevre hukukunun da gelişimini etkilemiştir. Dolayısıyla, Avrupa çevre hukukunun önemli bir kısmı mevzuat kitaplarına girerek çevre sorunları Bakanlar Konseyi'nin gündeminde üst sıralarda yerini almıştır. Ayrıca çevre meseleleriyle ilgili anlaşmazlıklar Avrupa Birliği Adalet Divanı'nın pek çok önemli kararına konu olurken $A B^{\prime}$ nin bu alandaki performansı, büyüyen bir bilimsel araştırma grubunun da odak noktası haline gelmiştir (McCormick, 2001, s. 1).

$A B$ çevre hukukunun üye devletlerin ulusal hukuk sistemlerinde yasal olarak uygulanması, Birlik genelinde yeknesaklığın korunması için merkezi bir gerekliliktir. Zira tek tip bir mevzuat uygulaması olmadan, iç pazar da olmazdı. Bununla birlikte Avrupa ve ulusal çevre hukuku arasındaki ilişki, özellikle AB yetkisinin varlığı ve kapsamı ile doğrudan bağlantılıdır (Proelss, 2016, s. 15).

Çok sayıda kirletici tarafından tehlikeye atılan tüketicilerin sağlığının çevre politikasının amaçları arasında yer almaması da önemli bir konudur. ${ }^{10}$ Kuşkusuz, çevre mevzuatından daha eski olan tüketiciyi koruma mevzuatı özel hukuk alanının kapsamındayken, çevre mevzuatı kamu hukukunun bir dalıdır. Ancak, sürdürülebilir kalkınma ve entegrasyon hükmünün etkisinin bir sonucu olarak, bu sınır giderek bulanıklaşmaktadır. Böylece, kamu hukuku bu alanda özel hukukla etkileşime girmeye yönlenmektedir. Hiç şüphe yok ki çevre, tüketiciyi koruma ve sağlığı koruma hukukları bir gün üçlü bir ittifak kurmak durumunda kalacaktır (Sadeleer, 2014, s. 35).

\footnotetext{
10 Tüketici sağlığı, AB tüketici politikasının TFEU'nun 169/1 maddesi altındaki hedeflerinden biridir.
} 


\section{Avrupa Birliği Hukukunda Çevre-Sağlık Mevzuatı}

$A B$ hukuku üç ana biçimde oluşur: Tüzükler, direktifler ve kararlar. Bir yasal düzenleme kabul edildiğinde, kabul edildiği yıl ve o yılki ardışık numaradan oluşan bir numara verilir. Tüzükler için önce sıra numarası, sonra yıl gelir. Dolayısıyla ozon tabakasına ilişkin tüzük 594/91 şeklinde numaralandırılmıştır. Direktifler ve kararlarda bunun tersi bir uygulama söz konusudur. Örneğin, hava kalitesine ilişkin direktif 96/62; ambalaj atıklarıyla ilgili karar 99/177 şeklindedir (McCormick, 2001, s. xvii).

Bu alandaki başlıca düzenlemelerden 2011/92/EU sayılı Direktif, çevre ile ilgili özel ya da resmi projelerin insan, hayvan, toprak, bitki, hava, maddi varlıklar üzerindeki doğrudan ve dolaylı olası etkilerinin tespit edilmesini gerekli kılmaktadır. Üye devletlerin, onay verilmeden önce doğası, boyutu veya konumu nedeniyle çevre üzerinde önemli etkileri olması muhtemel projelerin, gerekli geliştirme izni ve bununla ilgili etkileri konusunda bir değerlendirmeye tabi olmasını sağlamak için tüm önlemleri alması gerekmektedir (madde 2). 2001/42/EC sayılı Direktif ise, plan ve programların çevre konusundaki olası etkilerinin irdelenmesi ve en az düzeye indirgenmeye çalışılması veya ortadan kaldırılması durumlarının değerlendirildiği bir aşamayı belirlemektedir. 2003/4/EC sayılı Direktif, çevresel bilgiye ulaşma ile ilgili koşulları belirtirken, çevresel bilginin ulaşabilirliği ve vatandaşlara duyurulması ile ilgili hususları düzenlemektedir. Direktifin $7 / 4$ maddesi gereğince üye devletler, Topluluk mevzuatı tarafından belirlenen herhangi bir özel yükümlülüğe halel getirmeksizin ister insan faaliyetlerinden ister doğal nedenlerden kaynaklansın, insan sağlığı veya çevreye yönelik yakın bir tehdit olması durumunda, tüm bilgilerin sağlanması için gerekli önlemleri alması gerekmektedir. Çevresel politika ve bunlara yönelik çalışmlara destek oluşturmak amacıyla Avrupa konumuna dair veri altyapısının sağlanmasını amaçlayan 2007/2/EC sayılı INSPIRE Direktifi de çevre başlığı altında yer alan düzenlemeler arasındadır (European Parliament and Council Directive 2007/2/EC).

$A B$ çevre mevzuat setine dahil yasal çerçeve hayli kapsamlıdır. Bu kapsama çevre ile ilgili düzenlemelerin yanında su ve hava kalitesi, doğanın korunması, kirlenme, kimyasallar, iklim değişikliği ve gürültü gibi birçok konu dahildir.

Topluluk'un hava kalitesi sorunlarına tepkisi 1970'lerde başlamış ve insan sağ|ı̆ı̆ı veya çevreyi korumaktan çok ticarette bozulmalardan kaçınma endişelerinden kaynaklanmıştır. 1980'lerden itibaren düzenlemelerde sağlık konusu öne çıkmaya başlamıştır. 80/779/EEC sayılı Direktifin arkasındaki neden insan sağlığını korumak iken, 85/203/EEC sayılı Direktif hem insan sağığını hem de çevreyi korumak için tasarlanmıştır (McCormick, 2014, ss. 184-186). 
Gelişmiş veya gelişmemiş ülke ayrımı yapmaksızın hava kirliliği ciddi sağlık problemlerine neden olmaktadır. Bu bağlamda $A B$ de kirliliğin azaltılması ve emisyonların kontrol edilmesi hususunda bir dizi direktif çıkararak bu zorlukla mücadele etmektedir (Friedrich, 2016, ss. 117-118). Hava kalitesiyle ilgili 2008/50/EC sayılı Direktifte uçucu organik bileşiklere ilişkin emisyon düzenlemeleri yer almaktadır. Hava Kalitesi Çerçeve Direktifi, tüm kirleticiler için ortak yöntemler aracılığıyla hava kalitesinin değerlendirilmesine, izleme gereklilikleri ve metotlarına, temiz hava plan ve programlarına ilişkin kurallar getirmektedir. Hava kirliliği ile insan sağlığı ilişkisinin sıklıkla vurgulandığı bu Direktif, çevre-sağlık ilişkisinin önemli bir göstergesidir. Direktif'in 1/1 maddesinde belirttiği hedef "Insan sağlığı ve bir bütün olarak çevre üzerindeki zararlı etkileri önlemek veya azaltmak için tasarlanmış ortam hava kalitesi için hedefler tanımlamak ve oluşturmak" şeklindedir. Kirletici, Tanımlar başlığında 2/2 maddede şu şekilde ifade edilmiştir: "Kirletici, ortam havasında bulunan ve insan sağlığı ve/veya bir bütün olarak çevre üzerinde zararlı etkileri olması muhtemel herhangi bir madde anlamına gelir." Madde 13 ile de 'İnsan sağlığının korunması için sınır değerler ve uyarı eşikleri' düzenlenmiştir. 15 ve 16. maddeler insan sağlığını korumaya yönelik teknik hükümler içermektedir.

Su kalitesi konusundaki mevzuatın temelini ise 2000/60/EC sayılı Su Çerçeve Direktifi oluşturmaktadır. Direktif Avrupa kapsamında suların korunmasını ve mevcut su sunumlarının iyileştirilmesini amaçlamaktadır. Ayrıca bu Direktif ile su politikası da Avrupa'da tek bir yasal çerçevede toplanmıştır (Aküzüm, Çakmak ve Gökalp, 2010, s. 71). Su Çerçeve Direktifi, entegre havza yönetimi ve halkın karar alma süreçlerine katılımı esasına dayalı olarak, $A B^{\prime}$ deki genel olarak tüm su alanlarının miktar ve kalite bakımından iyileştirilip korunmasını öngören ana yasal düzenlemedir. Direktif'in 35 numaralı resitali çevresel kalite standardının gerek çevreyi korumak gerekse insan sağlığını korumak için aşılmaması gerektiği anlamına geldiğini vurgulamıştır (European Parliament and Council Directive 2000/60/EC).

Atık yönetiminde $A B^{\prime}$ nin temel ilkeleri; üreticinin sorumluluğu, kirleten öder, yeterlilik (yeter miktarda tesis), yakınlık ve atık yönetimi hiyerarşisidir. 2008/98/EC sayılı Atık Çerçeve Direktifinde tanımlanan atık yönetimi hiyerarşisine göre, atık yönetimi stratejileri atıkların oluşumunun kaynağında önlenmesine öncelikle odaklanmalıdır. Direktifin konu ve kapsamı, Direktif'in 1. maddesinde, atık üretimi ve yönetiminin olumsuz etkilerini önleyerek veya azaltarak, kaynak kullanımının genel etkilerini azaltarak ve bu tür kullanımın verimliliğini artırarak çevreyi ve insan sağlığını korumaya yönelik önlemleri ortaya koymak şeklinde ifade edilmiştir. Ayrıca Direktif'in 13. maddesi 'insan sağlığının ve çevrenin korunması' başlığını taşımaktadır (European Parliament and Council Directive 2008/98/EC). 
NATURA 2000, doğa koruma hususunda $A B^{\prime}$ nin en temel mevzuatı olarak adlandırılmaktadır. Bu mevzuat koruma ağlarının oluşturulması vasıtasıyla biyolojik farklılıkların korunmasını amaçlayan 92/43/EEC sayılı Habitat Direktifidir. Direktifin 6/4 maddesinin ikinci paragrafında geçen sağlık vurgusu şöyledir: "ilgili sahanın öncelikli bir doğal yaşam alanı tipine ve/veya öncelikli bir türe ev sahipliği yaptığı durumlarda, çevre için birincil öneme sahip faydalı sonuçlara veya Avrupa Komisyonu'nun görüşüne ek olarak, ilgili kamu yararını geçersiz kılan diğer zorunlu nedenlere karşı insan sağlığı veya kamu güvenliği öne sürülebilecek tek husustur." (Council Directive 92/43/EEC, 1992). Bu konuda bir başka direktif ise 2009/147/EC sayılı Kuş Direktifidir. Sağlık ile ilgili tek hüküm Direktif'te 9. maddede geçmektedir. Madde hükmüne göre, üye devletler, tatmin edici başka bir çözüm bulunmadığında, halk sağlığı ve güvenliği yararına, Direktif'in 5 ila 8. maddeleri hükümlerinden sapabilir (European Parliament and Council Directive 2009/147/EC).

Endüstriyel kirlenmenin kontrolü ve risk yönetimi başlığındaki temel düzenlemeler 2010/75/EC sayılı Endüstriyel Emisyonlar Direktifi ve 2012/18/EU sayılı Tehlikeli Maddeler İçeren Büyük Kaza Risklerinin Kontrolüne İlişkin Direktiftir. Endüstriyel Emisyonlar Direktifi, entegre izin sistemi ile kirliliğin üretim esnasında önlenmesi, üretim nedeniyle meydana gelen kirliliğin kontrolü, olası en iyi teknikler ve vatandaşların katılımı konularını düzenleyen 2008/1/EC sayılı Entegre Kirlilik Önleme ve Kontrol Direktifi'nin diğer 6 sektörel direktif ${ }^{11}$ in birleştirilerek tek direktif haline getirilmiş şeklidir (European Parliament and Council Directive 2008/1/EC).

Kimyasallar alanında iki önemli düzenleme mevcuttur: 1272/2008/EC sayılı madde ve karışımların tasniflendirilmesi, etiketlendirilmesi ve paketlenmesi Tüzüğü ile 1907/2006/EC sayılı Kimyasalların Kaydı, Değerlendirilmesi, İzni ve Kısıtlanması (Registration, Evaluation, Authorisation and Restriction of Chemicals/REACH) Tüzüğü. i̇ki Tüzük de sağlık konusunda benzer vurgular yapmaktadır. 1272/2008/EC sayılı Tüzük'ün dibacesinin ilk maddesinde insan sağlığına vurgu yapılmıştır: "Bu Tüzük, rekabeti ve yeniliği artırırken, insan sağlığı ve çevrenin yüksek düzeyde korunmasının yanı sıra kimyasal maddelerin, karışımların ve belirli özel maddelerin serbest dolaşımını sağlamalıdır." Aynı önem Tüzük'ün 1. maddesinde de gösterilerek şöyle ifade edilmiştir: "Bu Tüzük'ün amacı, madde 4/8' de atıfta bulunulan madde, karışım ve nesnelerin serbest dolaşımının yanı sıra insan sağlığı ve çevrenin yüksek düzeyde korunmasını sağlamaktır." Aynı durum 1907/2006/EC sayılı REACH Tüzüğü için de geçerlidir. Tüzük'ün dibacesinin ilk

\footnotetext{
11 Söz konusu 6 sektörel Direktif; Büyük Yakma Tesisleri Direktifi (2001/80/EC), Atık Yakma Direktifi (2000/76/EC), Solvent Emisyonları Direktifi (1999/13/EC), Titanyum Dioksit Sanayisinden Kaynaklanan Atıklara iliş̧kin 3 Direktif (78/176/EEC, 82/883/EEC, 92/112/EEC)'dir.
} 
maddesi Tüzük'ün, rekabet gücünü ve yeniliği artırırken, insan sağlığı ve çevrenin yüksek düzeyde korunmasını sağlaması gerektiğinin altını çizmektedir. Tüzük'ün 1/1 maddesinde de bu gereklilik aynen teyit edilmiştir. REACH Tüzüğü'nün 'Amaç ve kapsam' başlıklı 1. maddesinin 1. paragrafı şunları sağlamaktadır: Bu Tüzüğün amacı, maddelerin tehlikelerinin değerlendirilmesi için alternatif yöntemlerin teşviki ve ayrıca iç pazarda maddelerin serbest dolaşımının yanı sıra rekabet ve inovasyon gücünü artırarak insan sağlığı ve çevrenin yüksek düzeyde korunmasını sağlamaktır (European Parliament and Council Regulation (EC) 1907/2006).

Gürültü konusunda, çevresel gürültünün değerlendirilmesi ve yönetimine ilişkin 2002/49/EC sayılı Çevresel Gürültü Direktifi bulunmaktadır. Direktif kapsamında sağlık vurgusu başlangıç kısmında yapılmış ve yüksek düzeyde sağlık ve çevre koruma sağlamak Topluluk politikasının bir parçasıdır ve izlenecek hedeflerden biri de gürültüye karşı koruma olduğu belirtilmiştir (res. 1). Direktifte hedeflerinin ortaya konulduğu 1/1 (c) hükmünde, gürültü haritalama sonuçlarına dayalı olarak, gerektiğinde ve özellikle maruziyet seviyelerinin insan sağ|ığı üzerinde zararlı etkilere neden olabileceği durumlarda çevresel gürültü kalitesini korumak amacıyla, üye devletler tarafından eylem planlarının benimsenmesi ifade edilmektedir. Zararlı etkiler ise, insan sağlığı üzerindeki olumsuz etkiler anlamına geldiği Direktif'in 3-b Tanımlar başlığında yapılmıştır (European Parliament and Council Directive 2002/49/EC).

İklim değişikliği konusunda iki düzenleme bulunmaktadır. 406/2009/EC sayılı Karar ve 2018/842/EU sayılı Tüzük. Karar'da sağlık konusuna ilişkin herhangi bir kayda rastlanmazken, Tüzük'te sadece bir kez sağlık kavramına değinilmiştir. Resital 9'da yer alan bu kayıtta, enerji verimliliğini artırmanın sera gazı emisyonlarında önemli düşüşler ile birlikte ayrıca çevreye ve sağ|ığa fayda sağlayabileceğine yer verilmiştir (European Parliament and Council Regulation (EC) 2018/842).

\section{Sonuç}

Çevre ve insanın sürekli ve karşılıklı etkileşim içinde bulunduğu bir gerçektir. Bu gerçeklikte, gelecekteki sonuçları çok da düşünülmeden yapılan insan temelli faaliyetlerin çevreye baskısı şüphesiz ki olumsuzdur. Özellikle 18. yüzyıldan sonra insan-çevre ilişkisinde çevre aleyhine değişmiş olan dengede insana düşen görev artık kendi refahı ve sağlıklı yaşamının devamı için bile olsa çevreyi korumak, onun sürdürülebilirliğini bozmadan tüketmektir.

Dört yüz elli milyona yakın (Brexit sonrası) insanın yaşadığı Avrupa Birliği sınırları içerisinde de çevre sorunları önem arz etmektedir. Bölgesel entegrasyonun etkileri daha geniş bir şekilde anlaşıldıkça ve üye devletler tarafından kabul gördükçe, çevre politika alanının 
Avrupa politikaları üzerindeki baskısı zamanla artmıştır. Avrupalıların artan zenginliği onları yalnızca iyi eğitimin sağlanması, sağlık hizmetlerinde iyileştirmeler ve temiz hava ve su sağlama çabaları gibi nitel konularla daha fazla ilgilenmeye teşvik etmekle kalmamış, aynı zamanda bölgesel entegrasyonun çevresel konulara çekilmesine yardımcı bir dizi etki doğurmuştur. Bu etkinin sonucunda Avrupa Birliği'nde; hava ve su kalitesi, gürültü kirliliği, kimyasalların kontrolü, atık yönetimi, pestisitlerin kullanımı, enerji verimliliği, asit yağmuru ve iklim değişikliği gibi birçok çevresel başlığı ele alan ve her geçen gün çerçevesi genişleyen bir mevzuat ortaya çıkmıştır. Çevrenin korunmasına dair oluşturulan bu çok önemli mevzuat, insan sağ|ığının korunmasının önceliği üzerine inşa edilmiştir. Avrupa Birliği çevre ve sağlığın korunmasında konunun hem yetki yönünden hem de politik ve hukuki çerçeveden gelişimine özen göstermektedir.

Avrupa Birliği'nin İşleyişine İlişkin Antlaşma'nın 4/2 (e) ve (k) maddesi uyarınca, hem çevre politikasının sağlık yönlerine ilişkin yetkileri hem de halk sağlığı konularında ortak güvenlik endişeleri paylaşılmakla beraber insan sağlığının korunması ve iyileştirilmesi, Antlaşmanın 6 (a) maddesi sayesinde tamamlayıcı bir yetki olarak kabul edilmiştir. Bununla birlikte sağlık ve çevre konularında Avrupa Birliği'nin müstakil bir yetkiyle donatılmadığı görülmektedir.

Çevre ve sağıık, Avrupanın ortak sorunlarını ele aldığı için AB düzeyinde şekillendirilmiştir. Fakat, kurumsal düzeyde hem AT Antlaşması'nda hem de TFEU'da çevre ve sağlık politikalarına yaklaşım eşit bir zeminde değildir. Hatta, çevre korumasından çok sağığın korunmasının tercih edilmesi ve değerler hiyerarşisinde sağlığın daha yüksek bir seviyeye yerleştirilmesi durumu söz konusudur. Özellikle hava, su ve atık yönetimi alanlarında olmak üzere çok sayıda direktifin amaçları arasında halk sağlığının korunması vardır.

Yaşanan gelişmelere bakıldığında öngörülebilir gelecekte de bu iki politika alanınının önemini koruyacağı hatta AB'nin diğer politika alanları arasında ön plana çıkabileceği rahatlıkla söylenebilir. Ancak, sağlıkta ortaya çıkabilecek her sorunun çevresel sorunlardan kaynaklandığını, çevrenin sağlık üzerinde doğrudan negatif etkisinin olduğunu söylemek de bir o kadar güçtür. Bu itibarladır ki, çevre-sağlık etkileşiminin karmaşıklığı ve belirsizliği yapılan çalışmalara daha geniş perspektiften yaklaşmayı gerektirmektedir. Geçmiş bilgi ve deneyimleri hatırda tutarak atılacak adımlar; ulusal, bölgesel ve hatta uluslararası platformlardan da alınacak destekle daha sağlam olacaktır. Avrupa Birliği'nin gerek üye devletlerle gerekse Dünya Sağlık Örgütü gibi uluslararası kuruluşlarla yaptığı işbirliği çalışmaları bu bağlamda oldukça değerlidir. 


\section{Makalenin Araştırma ve Etik Beyanı Bilgileri}

\begin{tabular}{l|l}
$\begin{array}{l}\text { Yazar Çıkar } \\
\text { Çatışması Beyanı }\end{array}$ & $\begin{array}{l}\text { Araştırmaya konu olan durum ve olgular ile yazarlar arasında herhangi bir } \\
\text { çıkar çatışması bulunmamaktadır. }\end{array}$ \\
$\begin{array}{l}\text { Yazar Katkı Oranı } \\
\text { Beyanı }\end{array}$ & $\begin{array}{l}\text { Sağlık ve Çevre Etkileşimine AB Perspektifinden Yaklaşmak isimli makalenin } \\
\text { tüm bölümleri üç yazar tarafından birlikte yazılmıştır. }\end{array}$ \\
\hline $\begin{array}{l}\text { Etik Kurul Onay } \\
\text { Belgesi }\end{array}$ & $\begin{array}{l}\text { Çalışmada etik kurul onayı söz konusu olmayıp, bilimsel etikle örtüşmeyen } \\
\text { herhangi bir eylem söz konusu değildir. }\end{array}$
\end{tabular}

\section{Kaynakça}

Aküzüm, T., Belgin, Ç., \& Gökalp, Z. (2010). Türkiye'de Su Kaynakları Yönetiminin Değerlendirilmesi. Tarım Bilimleri Araştırma Dergisi, 1(1), 67-74.

Aydın, A. H., \& Ç. Ömer. (2017). Avrupa Birliği Çevre Politikaları ve Çevre Eylem Programları Üzerine Bir İnceleme. Bingöl Üniversitesi Sosyal Bilimler Enstitüsü Dergisi, 7(13), 27-44.

Charter of Fundamental Rights of the European Union (EU CFR), [2012] OJ C 326 Eylül 16, 2021 tarihinde http://data.europa.eu/eli/treaty/char_2012/oj adresinden alındı.

Carson, R. (2004). Sessiz Bahar. (Ç. Güler Çev.) Ankara: Palme Yayıncılık.

Club of Rome. (1972). The Limits to Growth. Kasım 28, 2021 tarihinde https://www.clubofrome.org/publication/the-limits-to-growth/ adresinden alındı.

Council Directive 80/779/EEC of 15 July 1980 on air quality limit values and guide values for sulfur dioxide and suspended particulates. [1980] OJ L229/30, Ekim 17, 2021 tarihinde http://data.europa.eu/eli/dir/1980/779/oj adresinden alındı.

Council Directive 85/203/EEC of 7 March 1985 on air quality standards for nitrogen dioxide. [1985] OJ L87/1, Ekim 17, 2021 tarihinde http://data.europa.eu/eli/dir/1985/203/oj adresinden alındı.

Council Directive 92/43/EEC of 21 May 1992 on the conservation of natural habitats and of wild fauna and flora. [1992] OJ L206/7, Ekim 16, 2021 tarihinde http://data.europa.eu/eli/dir/1992/43/oj adresinden alındı.

Council Directive 93/68/EEC of 22 July 1993 amending Directives 87/404/EEC (simple pressure vessels), 88/378/EEC (safety of toys), 89/106/EEC (construction products), 89/336/EEC (electromagnetic compatibility), 89/392/EEC (machinery), 89/686/EEC (personal protective equipment), 90/384/EEC (non- 
automatic weighing instruments), 90/385/EEC (active implantable medicinal devices), 90/396/EEC (appliances burning gaseous fuels), 91/263/EEC (telecommunications terminal equipment), 92/42/EEC (new hot-water boilers fired with liquid or gaseous fuels) and 73/23/EEC (electrical equipment designed for use within certain voltage limits). [1993] OJ L220/1, Ekim 18, 2021 tarihinde http://data.europa.eu/eli/dir/1993/68/oj adresinden alındı.

Çokgezen, J. (2007). Avrupa Birliği Çevre Politikası ve Türkiye. Marmara Üniversitesi iiBF Dergisi, XXIII(2), 91-115.

Dederer, H. G. (2016). The Challenge of Regulating Genetically Modified Organisms in the European Union: Trends and Issues. Y. Nakanishi (Ed.) içinde, Contemporary Issues in Environmental Law: The EU and Japan, (s. 139-168). Japan: Springer.

European Environmental Agency (2019). Environmental and Health. Eylül 16, 2021 tarihinde https://www.eea.europa.eu/tr/themes/human/intro adresinden alındı.

European Parliament and Council Decision No 406/2009/EC of 23 April 2009 on the effort of Member States to reduce their greenhouse gas emissions to meet the Community's greenhouse gas emission reduction commitments up to 2020. [2009] OJ L140/136, Ekim 22, 2021 tarihinde http://data.europa.eu/eli/dec/2009/406/oj adresinden alındı.

European Parliament and Council Directive 2000/60/EC of the of 23 October 2000 establishing a framework for Community action in the field of water policy. [2000] OJ L327/1, Ekim 25, 2021 tarihinde http://data.europa.eu/eli/dir/2000/60/oj adresinden alındı.

European Parliament and Council Directive 2001/42/EC of 27 June 2001 on the assessment of the effects of certain plans and programmes on the environment. [2001] OJ L197/30, Ekim 21, 2021 tarihinde http://data.europa.eu/eli/dir/2001/42/oj adresinden alındı.

European Parliament and Council Directive 2002/49/EC of 25 June 2002 relating to the assessment and management of environmental noise. [2002] OJ L189/12, Ekim 25, 2021 tarihinde http://data.europa.eu/eli/dir/2002/49/oj adresinden alındı.

European Parliament and Council Directive 2003/4/EC of 28 January 2003 on public access to environmental information and repealing Council Directive 90/313/EEC. [2003] OJ L041/26, Ekim 20, 2021 tarihinde http://data.europa.eu/eli/dir/2003/4/oj adresinden alındı.

European Parliament and Council Directive 2007/2/EC of 14 March 2007 establishing an Infrastructure for Spatial Information in the European Community (INSPIRE). [2007] OJ L108/1, Ekim 20, 2021 tarihinde http://data.europa.eu/eli/dir/2007/2/oj adresinden alındı. 
European Parliament and Council Directive 2008/1/EC of 15 January 2008 concerning integrated pollution prevention and control. [2008] OJ L 24, Ekim 20, 2021 tarihinde http://data.europa.eu/eli/dir/2008/1/oj adresinden alındı.

European Parliament and Council Directive 2008/50/EC of 21 May 2008 on ambient air quality and cleaner air for Europe. [2008] OJ L152/1, Ekim 20, 2021 tarihinde http://data.europa.eu/eli/dir/2008/50/oj adresinden alındı.

European Parliament and Council Directive 2008/98/EC of 19 November 2008 on waste and repealing certain Directives. [2008] OJ L312/3, Ekim 20, 2021 tarihinde http://data.europa.eu/eli/dir/2008/98/oj adresinden alındı.

European Parliament and Council Directive 2009/147/EC of 30 November 2009 on the conservation of wild birds. [2009] OJ L20/7, Ekim 20, 2021 tarihinde http://data.europa.eu/eli/dir/2009/147/oj adresinden alındı.

European Parliament and Council Directive 2010/75/EU of 24 November 2010 on industrial emissions (integrated pollution prevention and control). [2010] OJ L334/17, Ekim 19, 2021 tarihinde http://data.europa.eu/eli/dir/2010/75/oj adresinden alındı.

European Parliament and Council Directive 2011/92/EU of 13 December 2011 on the assessment of the effects of certain public and private projects on the environment. [2012] OJ L 26/1, Ekim 15, 2021 tarihinde http://data.europa.eu/eli/dir/2011/92/oj adresinden alındı.

European Parliament and Council Directive 2012/18/EU of 4 July 2012 on the control of major-accident hazards involving dangerous substances, amending and subsequently repealing Council Directive 96/82/EC. [2012] OJ L197/1, Ekim 22, 2021 tarihinde http://data.europa.eu/eli/dir/2012/18/oj adresinden alındı.

European Parliament and Council Regulation (EC) No 178/2002 of 28 January 2002 laying down the general principles and requirements of food law, establishing the European Food Safety Authority and laying down procedures in matters of food safety. [2002] OJ L31/1, Ekim 20, 2021 tarihinde http://data.europa.eu/eli/reg/2002/178/oj adresinden alındı.

European Parliament and Council Regulation (EC) No 1829/2003 of 22 September 2003 on genetically modified food and feed. [2003] OJ L268/1, Ekim 18, 2021 tarihinde http://data.europa.eu/eli/reg/2003/1829/oj adresinden alındı.

European Parliament and Council Regulation (EC) No 1907/2006 of 18 December 2006 concerning the Registration, Evaluation, Authorisation and Restriction of Chemicals (REACH), establishing a European Chemicals Agency, amending Directive 1999/45/EC and repealing Council Regulation (EEC) No 793/93 and Commission Regulation (EC) No 1488/94 as well as Council Directive 76/769/EEC and Commission Directives 91/155/EEC, 93/67/EEC, 93/105/EC and 2000/21/EC. 
[2006] OJ L396/1, Ekim 22, 2021 tarihinde http://data.europa.eu/eli/reg/2006/1907/oj adresinden alındı.

European Parliament and Council Regulation (EC) No 1272/2008 of 16 December 2008 on classification, labelling and packaging of substances and mixtures, amending and repealing Directives 67/548/EEC and 1999/45/EC, and amending Regulation (EC) No 1907/2006. [2008] OJ L353/1, Ekim 21, 2021 tarihinde http://data.europa.eu/eli/reg/2008/1272/oj adresinden alındı.

European Parliament and Council Regulation (EC) No 1107/2009 of 21 October 2009 concerning the placing of plant protection products on the market and repealing Council Directives 79/117/EEC and 91/414/EEC. [2009] OJ L309/1, Ekim 19, 2021 tarihinde http://data.europa.eu/eli/reg/2009/1107/oj adresinden alındı.

European Parliament and Council Regulation (EU) 2018/842 of 30 May 2018 on binding annual greenhouse gas emission reductions by Member States from 2021 to 2030 contributing to climate action to meet commitments under the Paris Agreement and amending Regulation 525/2013/EU. [2018] OJ L156/26, Ekim 21, 2021 tarihinde http://data.europa.eu/eli/reg/2018/842/oj adresinden alındı.

Friedrich, R. (2016). Integrated Assessment of Policies for Reducing Health Impacts Caused by Air Pollution. J. M. Pacyna, \& E. G. Pacyna (Ed.) içinde, Environmental Determinants of Human Health, (s. 117-132). Switzerland: Springer International Publishing.

Gevers, S. (2004). The Right to Health Care. European Journal of Health Law, 11(1), 2934.

Grossberndt, S., \& Liu H. Y. (2016). Citizen Participation Approaches in Environmental Health. J. M. Pacyna, \& E. G. Pacyna (Ed.) içinde, Environmental Determinants of Human Health (s. 225-248). Switzerland: Springer International Publishing.

Hervey, T. (2010). The Impacts of European Union Law on the Health Care Sector: Institutional Overview. Eurohealth, 16(4), 5-7.

Hervey, T., \& Vanhercke B. (2010). Health Care and the EU: The Law and the Policy Patchwork. E. Mossialos, G. Permanand, R. Baeten, \& T. K. Hervey (Ed.)içinde, Health Systems Governance in Europe: The Role of EU and Policy, (s. 84-133). Cambridge: Cambridge University Press.

Hoover, A. G. (2019). Defining Environmental Health Literacy. S. Finn, \& L. R. O'Fallon (Ed.) içinde, Environmental Health Literacy, (s. 3-18). Cham: Springer.

Jordan, A. (2005). European Union Environmental Policy - Actors, Institutions and Policy Processes. A. Jordan (Ed.) içinde, Environmental Health Literacy, (s. 1-15). Earthscan.

Karjalainen, T. K. (2016). Environment and Health Research Funded by the European Union (EU) Research Framework Programmes: Increasing Scientific Knowledge 
and Building a Solid Evidence-Base for Policy Making. J. M. Pacyna, \& E. G. Pacyna (Ed.) içinde, Environmental Determinants of Human Health (s. 249-264). Switzerland: Springer International Publishing.

Kemseke, P. V. (2020). How Covid-19 is changing the European Union. Euobserver, Eylül 4, 2021 tarihinde https://euobserver.com/opinion/149167 adresinden alındı

McCormick, J. (2014). Avrupa Birliğini Anlamak. (Y. Şahin \& H. H. Şahin Çev.). Ankara: BigBang Yayınları.

McCormick, J. (2001). Environmental Policy in the European Union. United Kingdom: Palgrave Macmillan.

McKee, M. (2017). 8.X. Workshop: How does the European Union contribute to its citizens' health?. European Journal of Public Health, 27(Ek 3), 243-244.

Nakanishi, Y. (2016). The Impact of the International and European Union Environmental Law on Japanese Basic Environmental Law. Y. Nakanishi (Ed.) içinde, Contemporary Issues in Environmental Law: The EU and Japan, (s. 1-14). Japan: Springer.

Ortolani, A. (2016). Environmental Damage Remediation in Japan: A Comparative Assessment. Y. Nakanishi (Ed.) içinde, Contemporary Issues in Environmental Law: The EU and Japan, (s. 185-198). Japan: Springer.

Proelss, A. (2016). The Scop of the EU's Competences on the Field of Environment. Y. Nakanishi (Ed.) içinde, Contemporary Issues in Environmental Law: The EU and Japan, (s. 15-28). Japan: Springer.

Rautio, A. (2016). Effects of Pollutant Exposure on Human Health as Studied with Selected EU Projects. J. M. Pacyna, \& E. G. Pacyna (Ed.) içinde, Environmental Determinants of Human Health, (s. 83-96). Switzerland: Springer International Publishing.

Sadeleer, N. D. (2014). EU Environmental Law and the Internal Market. Oxford: Oxford University Press.

T.C. Dışişleri Bakanlığı Avrupa Birliği Başkanlığı. (2020). Fasıl 27: Çevre ve İklim Değişikliği. Avrupa Birliği Başkanlığı, Ekim 18, 2021 tarihinde https://www.ab.gov.tr/fasil27-cevre_92.html adresinden alındı.

Treaty on European Union (TEU) (Consolidated version). [2012] OJ C326/13, Ekim 18, 2021 tarihinde http://data.europa.eu/eli/treaty/teu_2012/oj adresinden alındı.

Treaty on the Functioning of the European Union (TFEU) (Consolidated version). [2012] OJ C326/47, Ekim 18, 2021 tarihinde http://data.europa.eu/eli/treaty/tfeu_2012/oj adresinden alındı.

Türkeş, M., \& Kılıç, G. (2004). Avrupa Birliği'nin İklim Değişikliği Politikaları ve Önlemleri. Çevre, Bilim ve Teknoloji, Teknik Dergi, 2, 35-52. 


\title{
Approaching Health and Environment Interaction from the European Union Perspective
}

\author{
Extented Abstract
}

\section{Purpose and Significance}

It is generally acknowledged that the environment is in close relationship with human and public health. The quality of the environment will be reflected in human and public health and will also affect the level of welfare. In this respect, it can be considered that the emphasis on human and public health is increasing all over the world, and these two fields, which are in a close relationship with each other, are evaluated together by evaluating the environment and health together.

As a matter of fact, mankind should protect the environment to protect its own health because human health is closely related to environmental factors. For instance, environmental assets are very crucial in matters such as clean air and fertile soil conditions to meet basic food needs. Furthermore, the importance of climate, especially in the prevention of natural disasters, cannot be denied. Nevertheless, the environment has a very crucial place among the channels where people are exposed to noise, polluted air, and dangerous and harmful chemicals. The World Health Organization (World Health Organization/WHO) states in its report on the prevention of diseases by creating a healthy environment, there are also causes arising from environmental impact. Preventing important environmental problems and increasing the quality of the environment can prevent diseases and improve human health. The closest example of this is the COVID-19 pandemic, which has shaken Europe as well as the whole world. The Covid 19 pandemic is largely an environmental crisis. From this point of view, it can be said that protecting environmental assets from deterioration or improving them when they are damaged has a very important role in the protection of public health.

This study aims to examine the interaction of the environment and health relationship, which is examined as separate policies in the literature. In this context, the policies implemented in the EU have been evaluated from three perspectives in terms of authority, policy, and legal aspects. 


\section{Method}

This study, in which due diligence on the environment-health relationship in the EU is made, has been formed under three main headings. Primarily, the relationship between environment and health was discussed at the conceptual level, and then the issue was analyzed separately from both the political and legal aspects to understand the EU's approach to the environment-health relationship. In the last chapter, the legal framework included in the EU environmental legislation set has been examined and its relationship with health has been tried to be established.

At this point, in general, the descriptive research model was preferred in the study, and the subject was discussed with the descriptive method. In addition, the main founding texts and EU legislation were used for the legal dimension of the study.

\section{Findings}

As for the situation in Europe, we see that the biggest environmental health risk is air pollution. Air pollution is closely related to heart disease, pulmonary diseases, and stroke. Exposure to air pollution is estimated to cause too many premature deaths in the EU. Additionally, exposure to noise from transportation and industry can cause serious risks such as sleep disorders, restlessness, etc. Furthermore, to obtain compensation in legal cases for environmental health damage, litigants often face several types of problems. Especially for plaintiffs, the problem of adequately demonstrating causality between events and harm is one of the most difficult to overcome, because the human health effects of many pollutants are still not fully understood. However, it is not always possible to pinpoint a harmful effect on a single cause. In this respect, it is only possible in the light of both technical and scientific data to conduct the proceedings in a healthy way in disputes arising from the environmenthealth relationship.

The EU is more effective at the regional rather than the national level in the field of environmental policy, which seeks solutions to environmental problems, according to the member states. As a result of this impact, legislation has emerged that covers a wide range of issues such as air and water quality, noise pollution, control of chemicals, waste management, energy efficiency, acid rain, and climate change, and its framework has expanded. It has not always been easy to agree on a common solution to such matters. However, efforts to develop environmental policies at the European level are helping to lead a healthier EU life. In addition, the increasing wealth of Europeans has encouraged them to become more concerned with qualitative issues such as improvements in health care and efforts to provide clean air and water. 
EU, especially working conditions, environment, consumer products, etc. focused on health protection. Although member states must fulfill their responsibilities in accordance with Union law in the organization and financing of health services, the authority in this field is in the hands of the member states. In EU health policy, EU treaties give the EU a very limited role in health, which is mainly left to national regulations. However, the EU sets priorities in many directly related areas such as health and coordination of social security systems.

Besides, the EU has an important funding program for research in both health and environmental fields. These are projects funded by Research and Technological Development Framework Programs, also called Framework Programs. Additionally, environmental and health research does not only contribute to the formation of a scientific knowledge base. These projects are also needed to create synergy for a solution by addressing the common problems of Europe.

Furthermore, it is a legal requirement that environmental law is legally implemented in the national legal systems of the member states in the EU. It is indispensable for ensuring uniformity in practice within the EU because without a uniform legal regulation and implementation, it would not be able to maintain its existence in the internal market.

\section{Discussion and Conclusions}

Consequently, it is obvious that the environmental and health policy areas will maintain their importance in the EU. As a matter of fact, it can be said that the EU may come to the fore among other policy areas in the recent period. However, it is equally difficult to say that every problem that may arise in health is caused by environmental problems and that the environment has a direct negative effect on health. In this respect, the complexity and uncertainty of the environment-health interaction requires a broader perspective on the studies. Steps to be taken on the path of past knowledge and experience; will be stronger with the support to be received from national, regional, and even international platforms.

Nonetheless, health in the context of human and public health; has a decisive influence on the shaping of environmental actions and processes. It is possible to say that the protection of human health has become a priority target in all actions and decisions of the EU, and it also largely overtakes the protection of the environment. 
